\title{
Calcium Antagonists, Cerebral Ischemia and Vasospasm
}

\author{
Bryce Weir
}

\begin{abstract}
The past fifteen years has seen the classification of diverse substances into a group known as calcium antagonists (CAs). They have a common ability to reduce the transmembrane transport of extracellular calcium ions $\left(\mathrm{CA}_{\mathrm{e}}{ }^{2+}\right)$. $\mathrm{This} \mathrm{flow}$ of calcium into vascular smooth muscle is ultimately associated with the development of tension and vasoconstriction. Some CAs appear to have a predilection for cerebral as opposed to systemic arteries and so may function as specific cerebral arterial vasodilators. It has been proposed that they might be useful in certain types of cerebral ischemia such as that due to arterial occlusion or prolonged vasoconstriction. Animal experiments and initial clinical trials give grounds for cautious optimism that CAs may become as useful in neurology as they have recently become in cardiology.
\end{abstract}

RÉSUMÉ: Depuis 15 ans plusieurs substances ont été groupées sous le vocable d'antagonistes du calcium (CAs). Ces substances ont la propriété commune de réduire le transport transmembranaire des ions de calcium extracellulaires. Ce flot de calcium vers les muscles vasculaires lisses sera éventuellement associé au développement de tension et de vasoconstriction. Certains antagonistes du calcium semblent posséder une prédilection pour les vaisseaux cérébraux et servent peut-être de vasodilatateurs des artères cérébrales. Ils pourraient donc être utiles dans certaines formes d'ischémie cérébrale telles les occlusions artérielles ou la vasoconstriction prolongée. Des essais chez l'animal et quelques essais cliniques sont encourageants.

Can. J. Neurol. Sci. 1984; 11:239-246

A variety of pharmacological, mechanical and electrical stimuli are capable of causing vascular smooth muscle cells to contract. $\mathrm{Ca}_{\mathrm{e}}{ }^{2+}$ enters the cell through potential dependent channels (PDCs) and receptor-operated channels (ROCs). When cytosolic intracellular calcium $\left(\mathrm{Ca}_{i}{ }^{2+}\right)$ levels rise to critical levels, these ions link to calmodulin and activate it. This $\mathrm{Ca}_{\mathrm{i}}{ }^{2+}$ calmodulin then interacts with myosin light chain kinase (MLCK) triggering the development of cross-linkages between myosin and actin which are associated with increased phosphorylation and mechanical shortening. Activation of the contractile apparatus may not be entirely due to phosphorylation of the myosin molecule but might involve the leiotonin system which is associated with thin filaments. Vasodilatation can be produced by a variety of mechanisms which lower $\mathrm{Ca}_{i}{ }^{2+}$. Excellent recent reviews of vascular smooth muscle mechanisms include those of Weiss (1981), Flaim and Zelis (1982), and Hartshorne and Mrwa (1982).

Calcium antagonists are also known as calcium channel blockers, calcium entry blockers and slow channel blockers. In the late sixties Fleckenstein was the first to group this structurally heterogeneous family of compounds on the basis of their common ability to reduce the transmembrane transport of $\mathrm{Ca}_{e}{ }^{2+}$ ions, thereby producing selective blockade of the slow inward current and electromechanical uncoupling in heart muscle (see Schwartz and Taira, 1983). Haas and Haertfelder (1962) had previously described the coronary vasodilator effect of verapamil and Ferrari (1970) linked this to a specific calcium-blocking action in vascular smooth muscle. Endo et al. (1975) found that the administration of nifedipine completely relieved symptoms in patients with Prinzmetal's variant angina, which results from coronary artery vasospasm. There has been an enormous upsurge of interest in the CAs in the past few years because of their applications in the treatment of cardiac arrhythmias, angina and hypertension. Recent reviews include those of Antman et al. (1980), Cohn (1982), Sonnenblick and Lesch (1982 and 1983), Low et al. (1982), Packer and Frishman (1982), Buhler et al. (1982) and Schwartz and Taira (1983). 


\section{Table 1}

\begin{tabular}{|c|c|c|}
\hline CAs & $=$ & $\begin{array}{l}\text { Calcium antagonists, calcium entry blocker. calcium } \\
\text { channel blocker, calcium blocker. slow channel blocker }\end{array}$ \\
\hline $\mathrm{Ca}_{\mathbf{c}}{ }^{2+}$ & $=$ & Extracellular calcium ion \\
\hline PDC & $=$ & $\begin{array}{l}\text { Potential dependent channel, voltage dependent } \\
\text { channel }\end{array}$ \\
\hline ROC & $=$ & Receptor-operated channel \\
\hline $\mathrm{Ca}_{\mathrm{i}}{ }^{2+}$ & $=$ & Intracellular calcium ion \\
\hline $\mathrm{La}^{3+}$ & $=$ & Lanthanum ion \\
\hline NE & $=$ & Norepinephrine \\
\hline $5 \cdot \mathrm{HT}$ & $=$ & Serotonin \\
\hline $\mathrm{K}^{+}$ & $=$ & Potassium ion \\
\hline VSP & $=$ & Vasospasm \\
\hline $\mathrm{SAH}$ & $=$ & Subarachnoid hemorrhage \\
\hline CBF & $=$ & Cerebral blood flow \\
\hline cAMP & $=$ & Cyclic adenosine monophosphate \\
\hline $1 D_{50}$ & $=$ & $\begin{array}{l}\text { Inhibitory dose, that concentration of drug causing a } \\
50 \% \text { decrease in the maximum contraction }\end{array}$ \\
\hline
\end{tabular}

Allen (1977) suggested that because vascular smooth muscle cells in cerebral arteries, unlike those in non-cerebral arteries, require $\mathrm{Ca}_{\mathrm{e}}{ }^{2+}$ to contract in response to a wide variety of agonists that agents such as verapamil might block contraction of cerebral arteries without interfering with noncerebral arterial tone.

\section{Selective Effect on Cerebral Vascular Smooth Muscle of Calcium Antagonists}

It is now likely that agents may exist within this group which have special affinity for the cerebral vascular smooth muscle cell membranes as opposed to those in systemic arteries, the myocardium or the brain. Considerable research activity in the last few years provides grounds for optimism that blocking the entry of calcium into the cerebral vascular smooth muscle cells might prevent or ameliorate vasospasm (VSP) following subarachnoid hemorrhage (SAH).

To be effective against cerebral arterial VSP, a drug must be able to relax or prevent contraction of cerebral arteries without relaxing systenic arteries to the degree that systemic hypotension occurs. Allen et al. (1976) showed that for cerebral arterial smooth muscle cells $\alpha$-adrenergic stimulation, as well as serotonin $(5-\mathrm{HT})$ and prostaglandin $\mathrm{F}_{2 \alpha}$ stimulation, depended solely on $\mathrm{Ca}_{\mathrm{e}}{ }^{2+}$. He suggested that the extent to which cerebral vascular smooth muscle cells depend on extrinsic sources of calcium might differentiate them from other classes of smooth muscle cells.

Hayashi and Toda (1977) exposed strips of canine cerebral arteries to $\mathrm{Ca}^{2+}$-free media and depolarized them by $\mathrm{K}^{+}$. They then studied the contractions induced by the addition of $\mathrm{Ca}^{2+}$ with and without the calcium blocker verapamil and the nonspecific vasodilator papaverine. They found that the effect of verapamil in interfering with transmembrane influx of $\mathrm{Ca}^{2+}$ was greater in cerebral than peripheral arteries. This affinity for cerebral arteries was different from the nonspecific vasodilating effect of papaverine.

Allen and Banghart (1979) studied six basilar and six femoral segments from twelve dogs and recorded cumulative log-dose response curves to 5- $\mathrm{HT}$, phenylephrine and $\mathrm{K}^{+}$in the presence and absence of $3 \times 10^{-8} \mathrm{M}$ nifedipine. This concentration of nifedipine reduced the maximal contraction to 5-HT in basilar artery to about $35 \%$ but there was no significant change for femoral artery. Maximal phenylephrine contraction in basilar artery was about $10 \%$ of control with nifedipine, but more than $70 \%$ in femoral artery. Nifedipine did reduce somewhat the contraction of femoral artery to $\mathrm{K}^{+}$.

Prostaglandin $F_{2} \propto$ constricted dog coronary, mesenteric and cerebral vessels in studies by Shimizu et al. (1980). Subsequent use of verapamil produced greater relaxation of the cerebral than other vessels. On the other hand, it produced equal relaxation when the contractions were induced by $\mathrm{K}^{+}$.

Van Breemen et al. (1980) conducted in vitro studies of rabbit aorta and demonstrated that lanthanum $\left(\mathrm{La}^{3+}\right)$ will block the passage of $\mathrm{Ca}_{\mathrm{e}}{ }^{2+}$ into arterial smooth muscle cells. Following the application of $\mathrm{La}^{3+}$, the rabbit aorta still contracted to NE. They concluded that NE and similar agents were able to release $\mathrm{Ca}^{2+}$ from an intracellular pool. These experiments were repeated on canine basilar and femoral arteries. The basilar gave no contraction after application of $\mathrm{La}^{3+}$ when pure $\alpha$-adrenergic agents or 5-HT were added. In contrast, femoral arteries gave a single or a series of contractions of decreasing amplitude. This significant difference between brain and systemic arteries suggested that pharmacologic means might exist to selectively prevent cerebral constriction or selectively stimulate cerebral vessel dilatation.

Towart and Kazda (1979) found in rabbit aortic strip preparations that $\mathrm{KCl}$-induced contractions were blocked by nimodipine, one of the CAs. NE-induced contractions were not blocked by nimodipine, but were by the $\alpha$-agonist blocker, phentolamine. NE probably produces contraction in this vascular tissue by release of internally stored $\mathrm{Ca}_{i}{ }^{2+}$. When the effects of nimodipine on rabbit saphenous and basilar arteries were compared, the contractions induced by potassium ion $\left(\mathrm{K}^{+}\right)$depolarization were inhibited on both preparations. However, basilar contractions to 5-HT, histamine, catecholamines, thromboxanes and blood constituents were inhibited much more potently than those of the saphenous artery (Towart et al., 1982).

The variability in responsiveness of different vascular smooth muscle populations to CAs was illustrated in the review by Vanhoutte (in Cohn, 1982) who showed that the basilar artery was inhibited by much lower concentrations of the CA flunarizine than gastrosplenic, coronary or tibial arteries. Pearce and Bevan (1983), in a preliminary report on the cerebrovascular actions of diltiazem, found that infusion rates of $30 \mathrm{mcg} / \mathrm{kg} / \mathrm{min}$ were effective in producing cerebral vasodilatation without any fall in total peripheral resistance, cardiac output, cerebral metabolic rate or mean arterial pressure. They interpreted the observed vasodilation in the absence of a significant change in cerebral metabolic rate to support the concept that cerebral vascular smooth muscle cells are more dependent on $\mathrm{Ca}_{e}{ }^{2+}$ than most other vascular smooth muscles. Other authors have also provided evidence that cerebral smooth muscle cells contain relatively small intracellular calcium pools and depend mainly on $\mathrm{Ca}_{\mathrm{e}}{ }^{2+}$ for their contractions (McCalden and Bevan, 1981; Nakayama and Kato, 1979; Toda, 1974).

McCalden and Bevan (1981) compared responses of segments of rabbit basilar and ear arteries to various agonists. They suggested that the steady state NE contraction in the 
basilar artery is almost entirely dependent on closely bound extracellular $\mathrm{Ca}_{e}{ }^{2+}$. The ear artery situation was different because there was an additional tightly bound intracellular $\mathrm{Ca}^{2+}$ pool present. This source was also present in basilar artery but contributed only to a shortlasting phasic component insensitive to verapamil. This is somewhat at variance with other studies which, for the most part, have pointed to the conclusion that cerebral vessels are entirely dependent on $\mathrm{Ca}_{\mathrm{e}}{ }^{2+}$ for all agonist contractions.

Towart (1981) compared rabbit basilar and saphenous arteries. In basilar artery, the sustained tonic phase to 5-HT contraction was potently inhibited $\left(\operatorname{ID}_{50}=7.3 \times 10^{-10} \mathrm{M} / \mathrm{L}\right)$ but the initial shortlived, phasic portion of the contraction was relatively unaffected. This was felt to indicate that the antagonism by nimodipine was not at the 5-HT receptor level but probably in the ROCs. Both the initial phasic and tonic 5-HT contractions were unaffected in saphenous artery in doses of nimodipine up to $2.4 \times 10^{-5} \mathrm{M} / \mathrm{L}$.

Hogestatt et al. (1982) evaluated the effects of nifedipine on $\mathrm{K}^{+}$-induced contractions and release of NE from sympathetic nerves in rabbit basilar and facial arteries. Facial arteries were much more responsive to NE than the basilar. Alpha-adrenergic blockers antagonized the responses to NE in both types of vessels. On the other hand, contractions evoked by $\mathrm{K}^{+}$were only slightly reduced by $\propto$-blockers. Nifedipine concentrations inhibited $\mathrm{K}^{+}$contractions in both basilar and facial arteries in a dose-dependent manner. The basilar artery was more affected. Fluorescent histochemical demonstration of NE revealed a dense network of adrenergic nerve fibers in the walls of basilar and facial artery. These vessels accumulated ${ }^{3} \mathrm{H}-\mathrm{NE}$ and released it upon depolarization with $\mathrm{K}^{+}$. The uptake and subsequent release was significantly reduced by desipramine. Nifedipine did not alter the $\mathrm{K}^{+}$-evoked ${ }^{3} \mathrm{H}$-NE efflux from sympathetic nerves in either of the two vessels studied. They thought that nifedipine inhibited $\mathrm{K}^{+}$-evoked contractions in basilar and facial arteries from rabbit without interfering with nerve-mediated NE release.

Kazda and Towart (1982) showed a dose-dependent inhibitory effect of the CA nimodipine on potassium $\left(\mathrm{K}^{+}\right)$-induced contractions of an isolated rabbit aortic strip in vitro. Higher concentrations of the same drug failed to inhibit NE-induced contractions in the same model. In contrast, nimodipine had a dramatic inhibitory effect on rabbit basilar, but not systemic artery, responses to 5-HT. Verapamil, a different $\mathrm{CA}$, is very effective in inhibiting PDCs in all vessel areas as well as ROCs in cerebral and coronary arteries (Flaim and Zelis, 1982).

Skarby et al. (1983) found that for isolated cat pial and mesenteric arteries that the relative order of potency for CAs was: nimodipine $>$ nifedipine $>$ D600 $>$ verapamil $>$ diltiazem. Nimodipine was five times as potent on cerebral as mesenteric arteries.

Using canine arteries, Muller-Schweinitzer and Neumann (1983) antagonized contractile responses to 5-HT using several different CAs of the dihydropyridine group. PN 200-110 was 70 times more potent on basilar than on mesenteric arteries, whereas nifedipine and nimodipine were 10 and 6 times more potent on basilar than mesenteric arteries.

There is therefore an accumulation of evidence which suggests that pharmacological differences between different regions of the vascular tree may be exploited using CAs to cause selective cerebral arterial dilatation without significant systemic dilatation and consequent hypotension.

\section{Cerebral Blood Flow and Calcium Antagonists}

\section{Animal Studies}

Most of the CAs appear to increase cerebral blood flow (CBF). This is best documented with the dihydropyridines, however it is not unique to them. $0.1 \mathrm{mg} / \mathrm{kg}$ of diltiazem produced a $30 \%$ increase in CBF (Sato et al., 1971). Diltiazem was studied in dogs by Pearce and Bevan (1983). At infusion rates of $30 \mathrm{mcg} / \mathrm{kg} / \mathrm{min}$, there was an increase in CBF of $16 \%$, a decrease in cerebrovascular resistance of $24 \%$ with no change in total peripheral resistance, cardiac output or mean arterial blood pressure. At $100 \mathrm{mcg} / \mathrm{kg} / \mathrm{min}$, there was a significant decrease in all measured variables.

Nifedipine, in anesthetized intact rats at a dose of $0.5 \mathrm{mg} / \mathrm{kg}$, caused a 33\% increase in CBF (Sandahl et al., 1978). In the normocapnic, normotensive dog, an intra-arterial injection of $0.01 \mathrm{mg} / \mathrm{kg}$ nimodipine increased the CBF by $70 \%$ without any change in the general hemodynamics or blood gases. Tanaka et al. (1980) found that $0.1 \mathrm{mg} / \mathrm{kg}$ of nimodipine in intact anesthetized cats caused a $20 \%$ increase in CBF. Kazda et al. (1979) showed in normoxic dogs and cats that cerebral and coronary blood flow showed dose-dependent increases with nimodipine in the range $0.01-1.0 \mathrm{mg} / \mathrm{kg}$, whereas mesenteric and renal blood flow did not change and skeletal muscle flow increased only slightly. Kazda and Towart (1982) found in dogs that CBF increased to about $15 \%$ following a sublingual dose of $0.1 \mathrm{mg} / \mathrm{kg}$, to about $25 \%$ at $0.31 \mathrm{mg} / \mathrm{kg}$, but no significant further increase occurred at $1 \mathrm{mg} / \mathrm{kg}$. The effects of nimodipine were tested on anesthetized baboons by Harper et al. (1981). A continuous intravenous infusion of $2 \mathrm{mcg} / \mathrm{kg} / \mathrm{min}$ caused a fall of mean arterial blood pressure of $12 \%$ at $30 \mathrm{~min}$, and $8 \%$ at $50 \mathrm{~min}$ following the start of infusion. Mean CBF showed 19 and $27 \%$ increases at the corresponding time intervals. There was no significant change in $\mathrm{CMRO}_{2}$. A continuous intracarotid infusion of $0.67 \mathrm{mcg} / \mathrm{kg} / \mathrm{min}$ caused an increase of CBF up to $57 \%$ which was further increased to $87 \%$ above control after the blood brain barrier had been disrupted with hyperosmolar urea. EEG studies showed no increase in electrocortical activity. Their conclusion was that nimodipine had no effect on cerebral metabolism but increased CBF. Harris et al. (1982) carried out additional studies on the effect of nimodipine on the cerebral circulation. Nimodipine infusion increased basal blood flow in the open skull primate model but not the closed. Autoregulation to increased blood pressure was little effected but there was severe impairment of response to changes in arterial $\mathrm{pCO}_{2}$ and autoregulation with hypotension. Residual regional blood flow following middle cerebral artery occlusion was significantly higher when nimodipine was used.

In unanesthetized rabbits intravenous infusion of $0.1 \mathrm{mcg} /$ $\mathrm{kg} / \mathrm{min}$ nimodipine produced a 2 -fold increase in cerebral blood flow and a 1.5-fold increase in myocardial blood flow without increasing flow to other organs or causing significant hypotension (Haws et al., 1983).

\section{Human Studies}

Angelino et al. (1975) found $1 \mathrm{mg} / \mathrm{kg}$ of nifedipine caused a $19 \%$ increase in CBF. Gelmers (1982) studied CBF with Xe $\mathrm{X}^{133}$ 
intracarotid injection technique in ten patients following acute ischemic strokes. Five patients received a dose of $15 \mathrm{mcg} / \mathrm{kg}$ and five received $30 \mathrm{mcg} / \mathrm{kg}$ body weight of nimodipine. The bolus injections lasted ten minutes. Following injection, all patients showed a dose-dependent increase in hemispheric blood flow. After nimodipine, nine of the patients showed similar changes in increased blood flow in the stroke areas compared to normal hemispheric flow. In three patients, the increase in the ischemic regions was relatively greater than the normal brain. One patient showed a fall in blood pressure from $140 / 80$ to $90 / 60$ with an associated bradycardia of $48 / \mathrm{min}$, for a couple of minutes. Spontaneous return to baseline values then occurred. Gaab et al. (1982) measured CBF before and 60 minutes after drug administration in seven patients who had an acute $\mathrm{SAH}$ within eight days of the study. All patients had shown an increasing neurologic deficit without focal intracranial bleeding, which suggested that cerebral VSP had developed. This was shown in five of seven patients by angiography. They gave oral bolus doses of 40,60 or $80 \mathrm{mgm}$ of nimodipine. A mean CBF increase of $14 \%$ was recorded. The initial arterial pressure was only moderately elevated and these values were not significantly changed by nimodipine. The least perfused regions showed relatively higher increases in CBF.

\section{Cerebral Ischemia, Potassium and Calcium}

\section{Pathophysiology of Ischemia and Infarction}

Raichle (1982) has reviewed the pathophysiology of brain infarction and concluded that partial ischemia causes a rise in extracellular fluid potassium which paradoxically stimulates metabolism and releases vasoconstrictors. A disturbance in calcium homeostasis within the ischemic cell appears to be the final determinant of cell death. The inability to restore mitochondrial function and evidence of plasma membrane damage are two phenomena which have consistently been associated with irreversible ischemic cell damage according to Farber et al. (1981). These changes are reversible upon reoxygenation only when the large increases in intracellular $\mathrm{Ca}_{\mathrm{i}}{ }^{2+}$ content that accompany the phospholipid depletion from the outer cellular membranes is prevented. The elevated cytosolic free $\mathrm{Ca}_{i}{ }^{2+}$ may be the mechanism underlying the activation of endogenous phospholipases which degrade the mitochondrial endoplasmic and plasma membranes. They emphasize the central role of excess $\mathrm{Ca}_{\mathrm{i}}{ }^{2+}$ in the initiation and evolution of ischemic cell injury.

The direct effect of $\mathrm{K}^{+}$on vascular smooth muscle is to cause membrane depolarization which in turn augments the entry of extracellular calcium through the opening of specific membrane PDCs. In ischemic tissues, especially brain, the concentration of $\mathrm{K}^{+}$in extracellular fluid can increase to the extent that activation of vascular smooth muscle can occur (Vanhoutte, in Cohn, 1982). The response to $\mathrm{K}^{+}$disappears as external $\mathrm{Ca}^{2+}$ is lowered. Astrup et al. (1977) found in baboons that somatosensory evoked potentials failed when CBF fell below $15 \mathrm{ml} / 100 \mathrm{gm} / \mathrm{min}$. Massive release of $\mathrm{K}^{+}$from cells occurred about $6 \mathrm{ml} / 100 \mathrm{gm} / \mathrm{min}$. In their model of middle cerebral artery occlusion with subsequent lowering of blood pressure by bleeding, terminal extracellular $\mathrm{K}^{+}$rose to 19,44 , 50 and $64 \mathrm{mmol} / \mathrm{L}$. Baldy-Mouliniere and Negre (1976) showed in cats that by perfusing the lateral ventricles with solutions of varying $\mathrm{K}^{+}$concentration that changes in CBF could be induced. Increases of up to $100 \%$ of control values were caused by mild hyperkalemia $(2.8 \mathrm{mEq} / \mathrm{l}$ to $6 \mathrm{mEq} / 1)$, but above that level $\mathrm{CBF}$ progressively decreased to the point where the maintenance of $\mathrm{K}^{+}$over $10 \mathrm{mEq} / 1$ for more than two hours resulted in total circulatory arrest.

\section{Total Brain Ischemia Models}

A seven minute period of total cerebral ischemia produced by neck tourniquet killed nine of ten cats studied by Hoffmeister et al. (1979). However, with pretreatment using nimodipine ( $\mathrm{mg} / \mathrm{kg}$ po $15 \mathrm{~min}$ before ischemia), nine of the ten cats survived. Papaverine was much less effective. Using the same experimental model, Kazda et al. (1979) found a postischemic, shortlasting hyperemia followed by a progressive reduction of $\mathrm{CBF}$ to less than $50 \%$ of the pre-insult levels within $150 \mathrm{~min}$. Fifteen cats pretreated with $1 \mathrm{mg} / \mathrm{kg}$ nimodipine orally showed the same reactive hyperemia lasting about 30 minutes, but thereafter there was no progressive fall and the postischemic mortality was reduced from 90 to $10 \%$. After such ischemia, the $\mathrm{K}^{+}$ concentration in CSF increased relatively more than the intracranial pressure (Kazda and Towart, 1982). They hypothesized that the fatal reduction in CBF following total ischemia was due to arterial vasospasm resulting from an increase in $\mathrm{Ca}^{2+}$ influx into the $\mathrm{K}^{+}$depolarized vascular smooth muscle. Subsequent studies failed to show an influence of nimodipine on the levels of elevated $\mathrm{K}^{+}$post-ischemia, so that it presumably prevents the post-ischemic vascular spasm by inhibiting the transmembrane influx of $\mathrm{Ca}_{e}{ }^{2+}$ normally resulting from the depolarization due to $\mathrm{K}^{+}$which leaks out of the intracellular space during ischemia (Kazda et al., 1982).

Steen et al. (1983) found that nimodipine improved CBF and neurological recovery after a period of complete cerebral ischemia in the dog. Temporary aortic ligation was carried out in 11 dogs. Immediately prior to this, they received $10 \mathrm{mcg} / \mathrm{kg}$ iv followed by an infusion of $1 \mathrm{mcg} / \mathrm{kg} / \mathrm{min}$ for 2 hours. Blood flow and metabolites were measured for 2 hours in six dogs. Neurologic recovery was evaluated 48 hours postischemia in five dogs. CBF was nearly doubled in the postischemic hypoperfusion period in the nimodipine-treated dogs. There was no significant effect on metabolism at this time. Nimodipine also improved neurological recovery in that four of five treated dogs were normal and one was moderately damaged, whereas six of seven controls were either severely damaged or dead. The authors believe that the delayed hypoperfusion state occurring after complete ischemia probably does contribute to the ultimate neurological damage and suggested that nimodipine offers a potential protective effect.

The first attempt to correlate actual brain tissue calcium content with biochemical and electrophysiological recovery following total cerebral ischemia was carried out by Hossman et al. (1983). Calcium content was highest in those regions showing the greatest acidosis and no functional or metabolic recovery after ischemia and recirculation. Unfortunately, the use of the $C A$ flunarizine did not reduce tissue calcium content.

\section{Regional Ischemia Models}

Berger et al. (1983) studied the efficacy of verapamil in preventing ischemic brain injury in rats. Pretreatment with $2 \mathrm{mg} / \mathrm{kg}$ 
intravenously was carried out one hour before severe forebrain ischemia was induced by four vessel occlusion. An additional 1 $\mathrm{mg} / \mathrm{kg}$ of verapamil was given intravenously immediately following the insult. Animals were sacrificed four hours later. Both the verapamil-treated and untreated postischemic animals showed a $25 \%$ depression of brain ATP and a $30 \%$ decrease of total adenylates. No statistically significant differences were detected for any metabolite. Brain water content was $78.3 \%$ in both treated and untreated groups. This particular CA in this model was therefore ineffective. Roy et al. (1983) carried out transorbital permanent middle cerebral artery occlusion in cats. They studied $\mathrm{CBF}$ using $\mathrm{H}_{2}$ clearance methods, evoked potentials, brain water and nonperfused brain volume. Verapamil 1-2 $\mathrm{mcg} / \mathrm{kg} / \mathrm{min}$, commencing 2 hours before occlusion and for 24 hours thereafter, was used as treatment. The verapamil-treated animals had more brain water and greater nonperfused volumes than nontreated animals. Blood flow was also lower in the verapamil-treated animals.

The effects of reduced CBF upon edema formation and extracellular ion hemostasis under nimodipine preloading was studied in baboons by Harris et al. (1982). Nimodipine was given by continuous infusion as a solution made up to $0.6 \mathrm{mcg} / \mathrm{kg} / \mathrm{min}$ at an infusion rate of $.2 \mathrm{ml} / \mathrm{min}$ into the lingual artery. Following middle cerebral artery occlusion, the threshold levels of blood flow for the development of cortical edema and for disturbances of ion hemostasis were increased. This raises the possibility that nimodipine interferes with cellular energy metabolism and increases the susceptibility of tissues to ischemic damage according to the authors.

Overall, the available evidence suggests that it is worthwhile to continue to investigate the CAs with respect to a possible cellular protective effect which may be independent of any vasodilatation.

There has been at least one clinical trial of a calcium antagonist following ischemic stroke. Sixty patients with ischemic stroke were allotted into two groups - one of which was treated with $40 \mathrm{mgm}$ nimodipine tid - within 24 to 48 hours after onset of symptoms. Preliminary results suggest that the treatment group improved more rapidly and to a greater extent (H.J. Gelmers, personal communication, 1983).

\section{Cerebral Vasospasm}

Vasospasm is an exaggerated constriction of the blood vessel wall. The basic contractile process is the same in all vascular smooth muscle and depends on the availability of activator calcium ions. The occurrence of VSP must be related in some way to $\mathrm{Ca}^{2+}$ handling (Van Nueten and Vanhoutte, 1981).

Several days following subarachnoid hemorrhage (SAH), the major arteries in the subarachnoid space which are exposed to thick clot go into constriction. This is maximal around day 6 to 8 and is frequently gone by day 12 . This VSP is associated with delayed ischemic neurologic deficits from brain infarction. With the possible exception of the initial destructive effects of the hemorrhage, VSP is considered to be the principal cause of morbidity and mortality following aneurysm rupture (Weir et al., 1978 and Weir, 1980).

Agents which may play a role in the genesis of chronic VSP following SAH include: whole blood, erythrocyte breakdown products, hemoglobin, thrombin, fibrin degradation products, prostaglandins, thromboxane- $\mathrm{a}_{2}$, uridine triphosphate, 5-HT, histamine, potassium, catecholamines, vasopressin, angiotensin and other neuropeptides (Towart, 1982).

Regardless of which, if any, of these agents are involved in the genesis of VSP, it may be possible to find a potent means of interfering with the final common pathway of chronic vasoconstriction and still avoid disrupting cardiac, systemic arterial and neuronal function. Some possibilities have been summarized by Towart (1982). They include calmodulin antagonists to prevent or reverse activation of the actomyosin complex by calcium, phosphodiesterase inhibitors to increase cyclic adenosine monophosphate (cAMP) and increase $\mathrm{Ca}_{i}{ }^{2+}$ sequestration intracellularly, prostacyclin analogues to increase cAMP and also increase $\mathrm{Ca}_{i}{ }^{2+}$ sequestration intracellularly and CAs to inhibit the influx of calcium into the vascular smooth muscle cells.

\section{In Vitro Interactions Between Calcium Antagonists and Vasospasm Agonists}

\section{Animal Tissues}

Okwuasaba et al. (1981) studied the effect of hemorrhagic human CSF on canine cerebral arteries and rat stomach fundus. Neither methysergide, a 5-HT antagonist, nor indomethacin, an inhibitor of prostaglandin synthesis, significantly diminished the contractions induced. However, the calcium antagonist D600 successfully antagonized the responses of both tissues.

Towart and Perzborn (1981) found that nimodipine inhibited carbocyclic thromboxane-induced contractions of cerebral arteries. This compound constricted both rabbit basilar and saphenous arteries. The contractions of the basilar artery but not the saphenous were potently inhibited by nimodipine. Towart (1981) postulated that the selective inhibition of the sustained tonic contraction of basilar artery is due to a selective inhibition by nimodipine of calcium movement through ROCs in this vessel. Agonist-induced activation of ROCs in peripheral blood vessels is not effected by calcium antagonists.

Because calcium antagonists may have specific blocking actions, whereas the origin of vasospasm is likely to be multifactorial, White et al. (1982) studied the effect of nimodipine on contractions in isolated canine basilar arteries produced by 5-HT, prostaglandin $\mathrm{F}_{2} \propto$, thrombin and whole blood. They found that nimodipine significantly inhibited the contractile responses induced by these diverse agonists whether it was given before or after the agonists. They suggested that in canine cerebral arteries, a common calcium influx channel is involved and the response is elicited by a variety of receptor mechanisms. This is the rationale for the use of nimodipine in the treatment of cerebral ischemia that often follows SAH.

Flaim and Zelis (1982) concluded that nifedipine induced a $50 \%$ inhibition of contractile activity at concentrations of $10^{-9} \mathrm{M}$ against $\mathrm{KCl}, 3 \times 10^{-7} \mathrm{M}$ against $\mathrm{NE}$ and $5-\mathrm{HT}$, and $10^{-8} \mathrm{M}$ against prostaglandin $F_{2 \alpha}$. As with verapamil, nifedipine was more active as a contraction inhibitor in cerebral arteries than more peripheral vessels. It was a more potent inhibitor of contraction to all agents than verapamil. The effects of seven calcium blockers on isolated cerebral arteries were studied. The mean of eight values for verapamil on cerebral arteries yielded an inhibitory dose $\left(\mathrm{ID}_{\mathrm{s}_{0}}\right)=5 \times 10^{-8} \mathrm{M}$. For nifedipine it was $6 \times 10^{-9} \mathrm{M}$ and for nimodipine it was the lowest concentration of all at $3 \times 10^{-9} \mathrm{M}$. 


\section{Human Arteries}

Pial vessels from patients were studied in vitro by Edvinsson et al. (1979). Contractions in isolated arteries were induced by $\mathrm{NE}$ and 5-HT and nifedipine was used to block these. They found that in doses of $0.1-0.2 \mathrm{mcg} / \mathrm{ml}$, contractions were effectively reduced to both amines. Nifedipine $(0.2 \mathrm{mcg} / \mathrm{ml})$ relaxed the contraction induced in human pial arteries to blood plasma. Brandt et al. (1981) studied the contractions induced in human pial and mesenteric arteries by $\mathrm{K}^{+}, \mathrm{NE}, 5-\mathrm{HT}$ and prostaglandin $\mathrm{F}_{2^{\alpha}}$. In human pial arteries, the CAs, nifedipine and nimodipine, both caused an almost complete relaxation of contraction induced by $\mathrm{K}^{+}$. A similar drug concentration in the relaxation of prostaglandin $F_{2 \alpha}$ contracted vessels was less. Nifedipine had a higher potency for relaxing cerebral than mesenteric arteries contracted by $\mathrm{K}^{+}$but no such difference was demonstrated for nimodipine. Both nifedipine and nimodipine effectively inhibited contractions induced by calcium in pial arteries pretreated in a calcium-free medium and depolarized by potassium. The results suggested that $\mathrm{K}^{+}$, amines and prostaglandin $F_{2^{\alpha}}$ activate isolated pial and mesenteric arteries by different calcium-dependent mechanisms and confirmed the potent relaxing effects of these CAs.

Blood induced contractions of human anterior cerebral arteries, obtained at autopsy, were effectively countered by CAs. The order of potency was PN 200-110 = nimodipine $>$ nifedipine (Muller-Schweinitzer and Neumann, 1983).

\section{In Vivo Interactions of Calcium Antagonists and Vasospasm Agonists}

\section{Canine Models}

Allen and Bahr (1979) treated dogs with nifedipine, $1 \mathrm{mg} / \mathrm{kg}$. In four dogs, two days after a SAH, the basilar artery was $57 \%$ of its control cross sectional area and this increased to $111 \% 30$ min after an oral dose of nifedipine. Three out of 12 dogs showed a drop from $180-160$ systolic to $140 \mathrm{~mm} / \mathrm{Hg}$ systolic within $10 \mathrm{~min}$ of the time nifedipine was given. The blood pressure remained stable or rose slightly during the following 20 min. Nagai et al. (1980) used single intravertebral artery injections in dogs and carried out angiography up to $30 \mathrm{~min}$ following induced SAH. The CAs, cinnarizine, nifedipine and verapamil, all induced relaxation at doses about $10^{-5} \mathrm{M}$. Nifedipine and verapamil produced some hypotension and verapamil produced some rise in intracranial pressure in this model. Varsos et al. (1983) induced chronic VSP in the dog model by giving two hemorrhages into the cisterna magna. On the fifth day after two blood injections, intravenous aminophylline, nifedipine $(1 \mathrm{mg} / \mathrm{kg}$ ) and the intra-arterial bolus injection of 2 $\mathrm{mg} / \mathrm{kg}$ papaverine all failed to reverse the constriction.

\section{Feline Models}

Brandt et al. (1980) obtained increases in baseline caliber of resting pial arterioles in cats, following acute subarachnoid bleeding, of $33-53 \%$ using perivascular application of nifedipine at concentrations of $0.1-10 \mu \mathrm{M}$. The diameters were measured using a television image splitting technique. Cohen and Allen (1980) compared the effects of nifedipine and nimodipine at a dose of $0.28 \mathrm{mg} / \mathrm{kg}$. In the dog model nifedipine, at this reduced dose, did not produce statistically significant relief of spasm whereas nimodipine did.
Tanaka et al. (1982) studied the effect of nimodipine on cerebral VSP after SAH in cats. The VSP was induced by injecting $0.2-0.3 \mathrm{ml}$ fresh autologous blood into the cisterna magna. Diameter of pial vessels was continually monitored by means of a television camera system. Intravenous administration of nimodipine $(0.1 \mathrm{mg} / \mathrm{kg}) 20-30 \mathrm{~min}$ after $\mathrm{SAH}$ resulted in a complete disappearance of the spasm. The vasodilatation was more marked in arteries under 100 microns than in those which were larger.

Brandt et al. (1983) studied cat cortical arterioles and venules under normal conditions and in focal ischemia, with and without the topical application of nifedipine. This drug produced a marked concentration-dependent arteriolar dilatation. The responses increased significantly with decreasing arteriolar size. Perivenular micro-application caused dilatation but it was less pronounced than that on the arteriolar side. Arterioles which had constricted following middle cerebral artery occlusion dilated following nifedipine application. On some occasions, there was return of flow in vessels in which stasis had been present.

Auer (1983) used a closed cranial window model in cats and found a $25 \%$ dilation of arterioles with a continuous infusion of $1 \mathrm{mcg} / \mathrm{kg} / \mathrm{min}$. While further dilation occurred with higher dose rates there was a progressive significant fall in systemic blood pressure. Pial venous diameters were unchanged.

\section{Primate Models}

Svendgaard et al. (1983) produced late cerebral arterial spasm by repeated injection of autologous blood in a total amount of 14 - $33 \mathrm{ml}$ into the basal cisterns of baboons. One week following the start of blood injection, there was about $10 \cdot 20 \%$ reduction in vessel caliber depending upon the territory measured. This was associated with an $18 \%$ reduction in CBF and a $9 \%$ decrease in brain metabolism. During hypercapnea before and after experimental SAH, the flow increased with a mean of 3.7 and $1.8 \mathrm{ml}$, respectively, for each $\mathrm{mm} / \mathrm{Hg}$ elevation of $\mathrm{PaCO}_{2}$. In control animals, graded angiotensin-induced hypertension did not affect CBF. Following SAH, the CBF autoregulation was impaired in five of six animals. The intravenous infusion of nimodipine markedly curtailed the CBF autoregulation in preSAH animals and to a lesser extent in post-SAH animals.

\section{Human Study}

In a double-blind study of pial arteries carried out during EC-IC bypass infusing $1 \mathrm{mcg} / \mathrm{kg} / \mathrm{min}$ of nimodipine intravenously, pial arteries between 25 and $70 \mu \mathrm{m}$ showed an $18 \%$ dilatation (Auer et al., 1983).

\section{Clinical Trials of Nimodipine Following Aneurysm Rupture}

\section{Intraoperative Use}

Auer et al. (1982) applied a $2.4 \times 10^{-5} \mathrm{M}$ solution of nimodipine to exposed cerebral vessels in 17 patients intraoperatively when ruptured aneurysms were being clipped. The operations were carried out between $\mathbf{4 2}-\mathbf{7 2}$ hours post-SAH. All patients had blood in the basal cisterns by CT scan. Vasodilatation was observed in all instances. The smaller vessels showed a relatively larger dilation. Only two patients had a postoperative neurological deficit combined with angiographically-verified VSP. Thirteen patients had a plastic cannula placed intraoperatively to permit postoperative topical administration of nimo- 
dipine. Postoperative control angiograms after a mean interval of seven days from SAH did not show severe VSP in any of the patients. It was concluded that topical intracisternal administration of nimodipine reversed intra-operative vascular spasm and decreased the probability of postoperative symptomatic VSP after early surgery.

\section{Prophylactic Use}

Allen et al. (1983) carried out a prospective, multi-institutional, double-blind, randomized, placebo-controlled trial of nimodipine in 125 neurologically normal patients who had aneurysm rupture. Treatment was started within 96 hours of the SAH. A deficit from cerebral VSP that persisted and was severe or caused death by the end of the 21 day treatment period occurred in 8 of 60 patients given placebo and 1 of 56 given nimodipine ( $\mathrm{p}=$ 0.03 , Fisher's exact test). In patients given placebo, the amount of blood on the pre-entry, initial CT scan correlated with the deficits attributed to VSP. The nimodipine-treated patients, on the other hand, showed no such correlation. There were no side effects from nimodipine in the dosage used which was 0.7 $\mathrm{mg} / \mathrm{kg}$ as a loading dose and then $0.35 \mathrm{mg} / \mathrm{kg}$ orally $\mathrm{q} 4 \mathrm{~h}$ for 21 days. Angiograms were carried out initially to make the diagnosis and then they were repeated if the patient developed a neurological deficit during the course of treatment. Since all patients did not have a repeat angiogram, it was impossible to come to a firm conclusion that nimodipine reduced the frequency and severity of angiographic VSP. Notwithstanding this, the evidence that it reduced neurological deficit and the chance of death from VSP was strong.

A recent anonymous Lancet editorial (1983) cites anecdotal evidence that nimodipine may not vastly reduce the incidence of angiographically demonstrable VSP.

\section{CONClusions}

The many gaps in our knowledge of basic mechanisms of vascular smooth muscle contraction mechanisms and the pharmacological complexities of the actions of CAs and their interactions with other drugs clearly point to the need for continued experimentation. It is important to develop drugs with the greatest possible selectivity for cerebral vascular calcium channels as well as to establish the most effective and safest dosage regimen and route of administration. Further controlled clinical trials are urgently needed to establish whether or not CAs are effective in protecting the brain from global and regional ischemia as well as preventing VSP and the development of delayed ischemic neurologic deficits.

\section{REFERENCES}

Allen GS (1977) Cerebral arterial spasm: a discussion of present and future research. Neurosurgery 1: 142-148.

Allen GS, Ahn HS, Preziosi TJ, Battye R, Boone SC, Chou SN, Kelly DL, Weir BK, Crabbe RA, Lavik PJ, Rosenbloom SB, Dorsey FC, Ingram CR, Mellits DE, Bertsch LA, Boisvert DPJ, Hundley MB, Johnson RK, Strom JA, Transou CR (1983) Cerebral arterial spasm - a controlled trial of nimodipine in patients with subarachnoid hemorrhage. New Engl. J. Med. 308: 619-624.

Allen GS, Bahr AL (1979) Cerebral arterial spasm: Part 10. Reversal of acute and chronic spasm in dogs with orally administered nifedipine. Neurosurgery 4: 43-47.

Allen GS, Banghart SB (1979) Cerebral arterial spasm: Part 9. In vitro effects of nifedipine on serotonin-, phenylephrine-, and potassium- induced contractions of canine basilar and femoral arteries. Neurosurgery $4: 37-42$.

Allen GS, Gross CJ, Henderson LM, Chou SN (1976) Cerebral arterial spasm: Part 4. In vitro effects of temperature, serotonin analogues. large nonphysiological concentration of serotonin, and extracellular calcium and magnesium on serotonin-induced contractions of the canine basilar artery. J. Neurosurg. 44: 585-593.

Angelino PF, Tortore P, Algranati R (1975) Hemodynamic studies on the new coronary therapeutic drug nifedipine (BAY a 1040). W. Lochner, W. Braasch, G. Kroneberg (Eds.), in 2nd International Adalat Symposium. New Therapy of Ischemic Heart Disease. New York: Springer-Verlag, pp. 128-139.

Antman EM, Stone PH, Muller JE, Braunwald E (1980) Calcium channel blocking agents in the treatment of cardiovascular disorders. Part 1. Basic and clinical electrophysiologic effects. Ann. Int. Med. 93: 875-885.

Astrup J, Symon L, Branston NM, Lassen NA (1977) Cortical evoked potential and extracellular $\mathrm{K}^{+}$and $\mathrm{H}^{+}$at critical levels of brain ischemia. Stroke 8: 51-57.

Auer L (1983) Cerebrovascular activity of the calcium antagonist nimodipine. M. Reivich and H.I. Hurtig (Eds.), in Cerebrovascular Diseases. New York, Raven Press, pp. 437.

Auer LM, Ito Z, Suzuki A, Ohta H (1982) Prevention of symptomatic vasospasm by topically applied nimodipine. Acta Neurochir. 63 : 297-302.

Auer LM, Oberbauer RW, Schalk HV (1983) Human pial vascular reactions to intravenous nimodipine-infusion during EC-IC bypass surgery. Stroke 14: 210-213.

Baldy-Moulinier M, Negre $\mathrm{Ch}(1976) \mathrm{K}^{+}$accumulation as a pathological stimulus for dilatation or contraction of cerebral vessels. In Betz E (Ed.), Ionic Actionson Vascular Smooth Muscle. New York, SpringerVerlag pp. 97-100.

Berger JR, Busto R, Ginsberg MD, Alonso O (1983) Calcium channel blocker: trial in global brain ischemia. Neurology 33 (Suppl. 2): 182.

Brandt L, Andersson K-E, Bengtsson B, Edvinsson L. Ljunggren B, MacKenzie ET (1980). Effect of a calcium antagonist on cerebrovascular smooth muscle in vitro and in vivo. In RH Wilkins (Ed.), Cerebral Arterial Spasm. Baltimore, Williams \& Wilkins, pp. 699.

Brandt L, Andersson K-E, Edvinsson L, Ljunggren B (1981) Effects of extracellular calcium and of calcium antagonists on the contractile responses of isolated human pial and mesenteric arteries. J. Cereb. Blood Flow Metab. 1: 339-347.

Brandt L, Ljunggren B, Andersson K-E, Edvinsson L, MacKenzie E, Tamura A, Teasdale G (1983) Effects of topical application of a calcium antagonist (nifedipine) on feline cortical pial microvasculature under normal conditions and in focal ischemia. J. Cereb. Blood Flow Metab. 3: 44-50.

Buhler FR, Hulthen UL, Bolli P (1982) Calcium channel inhibitors for identification of mechanisms and treatment of hypertension. Cardiovasc. Pharm. 4 (Suppl. 3): S 267 - S 391.

Cohen RJ, Allen GS (1980) Cerebral arterial spasn: the role of calcium in in vitro and in vivo analysis of treatment with nifedipine and nimodipine. In RH Wilkins (Ed.), Cerebral Arterial Spasm. Baltimore, Williams \& Wilkins, pp. 699.

Cohn JN (1982) Calcium-entry blockers in coronary artery disease. Circulation 65 (Part II): 11 - I 59.

Editorial (1983) Calcium antagonists and aneurysmal subarachnoid hemorrhage. Lancet II: 141-143.

Edvinsson L, Brandt L, Andersson K-E, Bengtsson B (1979) Effect of a calcium antagonist on experimental constriction of human brain vessels. Surg. Neurol. 11: 327-330.

Endo M, Kanda I, Hosoda S, Hayashi H, Hirosawa K, Konno S (1975) Prinzmetal's variant form of angina pectoris: re-evaluation of mechanisms. Circulation 52: 33-37.

Farber JL, Chien KR, Mittnacht Jr., S (1981) The pathogenesis of irreversible cell injury in ischemia. Amer. J. Path. 102: 271-281.

Ferrari M (1970) Interactions between calcium and some myolytic agents on depolarized vascular smooth muscle. J. Pharm. Pharmacol. 22: 71.72 .

Flaim SF, Zelis R (1982) Calcium Channel Blockers: Mechanisms of Action and Clinical Applications. Baltimore, Urban \& Schwarzenberg, pp. 303.

Gaab MR, Brawanski A, Bockhorn J, Haubitz l, Rode ChP, Maximilian VA (1982) Calcium antagonism: a new therapeutic principle in stroke and cerebral vasospasm? rCBF Bull. 3: 47-51. 
Gelmers HJ (1982) Effect of nimodipine (Bay e 9736) on postischaemic cerebrovascular reactivity, as revealed by measuring regional cerebral blood flow (rCBF). Acta Neurochir. 63: 283-290.

Haas H, Haertfelder G (1962) a-lsopropyl-a-((N-methyl-N-homoveratril) -a-aminopropyl)-3, 4-dimethoxyphenylacetonitril, eine substanz mit koronargefasserweiternden eigenschaften. Arzneim. Forsch. 12: 1549-1558.

Harper AM, Craigen L, Kazda S (1981) Effect of the calcium antagonist, nimodipine, on cerebral blood flow and metabolism in the primate. J. Cereb. Blood Flow Metab. 1: 349-356.

Harris RJ, Branston NM, Symon L, Bayhan M, Watson A (1982) The effects of a calcium antagonist, nimodipine, upon physiological responses of the cerebral vasculature and its possible influence upon focal cerebral ischaemia. Stroke 13: 759-766.

Hartshorne DJ, Mrwa U (1982) Regulation of smooth muscle actomyosin. Blood Vessels 19: 1-18.

Haws CW, Gourley JK, Hevstad DD (1983) Effects of nimodipine on cerebral blood flow. Pharmacol. Exper. Therap. 225: 24-28.

Hayashi S, Toda $\mathrm{N}$ (1977) Inhibition by $\mathrm{Cd}^{2+}$, verapamil and papaverine of $\mathrm{Ca}^{2+}$-induced contractions in isolated cerebral and peripheral arteries of the dog. Brit. J. Pharmacol. 60: 35-43.

Hoffmeister F, Kazda S, Krause HP (1979) Influence of nimodipine (Bay e 9736) on the postischaemic changes of brain function. Acta Neurol. Scand. 60 (Suppl. 72): 358-359.

Hogestatt ED, Andersson KE, Edvinsson L (1982) Effects of nifedipine on potassium-induced contraction and noradrenaline release in cerebral and extracranial arteries from rabbit. Acta Physiol. Scand. 114: 283-296.

Hossman KA, Paschen W, Csiba L (1983) Relationslip between calcium accumulation and recovery of cat brain after prolonged cerebral ischemia. J. Cereb. Blood Flow Metab. 3: 316-353.

Kazda S, Hoffmeister F, Garthoff B, Towart R( 1979) Prevention of the postischaemic impaired reperfusion of the brain by nimodipine (Bay e 9736). Acta Neurol. Scand. 60 (Suppl. 72): 302-303.

Kazda S, Towart R (1982) Nimodipine: a new calcium antagonistic drug with a preferential cerebrovascular action. Acta Neurochir. 63: 259-265

Kazda S, Garthoff B, Krause HP, Schlossmann K (1982) Cerebrovascular effects of the calcium antagonistic dihydropyridine derivative nimodipine in animal experiments. Arzneim. Forsch. 32: 331-338.

Low RI, Takeda P, Mason DT, DeMaria AN (1982) The effects of calcium channel blocking agents on cardiovascular function. Am. J. Cardiol. 49: 547-553.

McCalden TA, Bevan JA (1981) Sources of activator calcium in the rabbit basilar artery. Am. J. Physiol. 241: H 129 - H 133.

Muller-Schweinitzer E, Neumann P (1983) In vitro effects of calcium antagonists PN 200-110, nifedipine, and nimodipine on human and canine cerebral arteries. J. Cereb. Blood Flow Metab. 3: 354-361.

Nagai H, Takagi T, Kamiya K, Fukuoka H, Hotta K (1980) Effect of vasoactive drugs on late spasm. In $\mathrm{RH}$ Wilkins (Ed.), Cerebral Arterial Spasm. Baltimore, Williams \& Wilkins, pp. 699.

Nakayama K, Kato H (1979) Different calcium dependency of contractile responses of cerebral artery to quick stretch and electrical stimuli. Acta Neurol. Scand. 60 (Suppl. 72): 508-509.

Okwuasaba FK, Weir BK, Cook DA, Krueger CA (1981) Effects of various intracranial fluids on smooth muscle. Neurosurgery 9: 402-406.

Packer M, Frishman WH (1982) Verapamil therapy for stable and unstable angina pectoris: calcium channel antagonists in perspective. Amer. J. Cardiol. 50: 881-885.

Pearce WJ, Bevan JA (1983) The cerebrovascular selectivity of diltiazem. Programme, Annual Meeting of American Association of Neurological Surgeons, Washington: 60-61.

Raichle ME (1982) The pathophysiology of brain ischenia and infarction. Clin. Neurosurg. 29: 379-389.

Roy MW, Tibbs PA, Holladay FP, Donaldson DL. Young AB (1983) Deleterious effects of verapamil following middle cerebral artery occlusion in cats. Programme, Annual Meeting of American Association of Neurological Surgeons. Washington: 58-59.

Sandahl B, Andersson KE, Aronsen KF, Ulmsten U (1978) Effect of the calcium antagonist nifedipine on uterine blood flow in nontreated and oestradiol-treated rats. Gynec. Obstet. Invest. 9: 238-243.
Sato M, Nagao T, Yamaguchi I, Nakajima H, Kiyomoto A (197I) Pharmacological studies on a new 1,5-benzothiazepine derivative (CRD-401). I. Cardiovascular actions. Arzneim. Forsch. 21: 1338-1343.

Schwartz A and Taira N, Editors (1983) Calcium channel-blocking drugs: a novel intervention for the treatment of cardiac disease. Circ. Res. 52 (Part II): I 1 - I 181.

Shimizu K, Ohta T, Toda N (1980) Evidence for greater susceptibility of isolated dog cerebral arteries to $\mathrm{Ca}$ antagonists than peripheral arteries. Stroke 11: 261-266.

Skarby T, Andersson KE, Edvinsson L (1983) Influence of extracellular calcium and calcium antagonists on contractions of isolated cerebral and mesenteric arteries. Programme. Synıposium - Der Zerebral Angiospasmus. Mainz. 62.

Sonnenblick EH, Lesch M (1982 and 1983) Calcium blockers. 1, 11, III. Progr. Cardiovasc. Dis. 25: 83-296.

Steen PA, Newberg LA, Milde JH, Michenfelder JD(1983) Nimodipine improves cerebral blood flow and neurologic recovery after complete cerebral ischemia in the dog. J. Cereb. Blood Flow Metab. 3: 38-43.

Svendgaard NA, Brismar J, Delgado T, Egund N, Owman C, Rodacki MA, Sahlin C, Salford LG (1983) Late cerebral arterial spasm: The cerebrovascular response to hypercapnia, induced hypertension and the effect of nimodipine on blood flow autoregulation in experimental subarachnoid hemorrhage in primates. Gen. Pharmacol. 14: $167-172$

Tanaka K, Gotoh F, Muramatsu F, Fukuchi Y, Amano T, Okayasu H, Suzuki N (1980) Effects of nimodipine (Bay E 9736) on cerebral circulation in cats. Arzneim. Forsch. 30: 1494-1497.

Tanaka K, Gotoh F, Muramatsu F, Fukuchi Y, Okayasu H, Suzuki N, Kobari M (1982) Effect of nimodipine, a calcium antagonist, on cerebral vasospasm after subarachnoid hemorrhage in cats. Arzneim. Forsch. 32: 1529-1534.

Toda N (1974) Responsiveness to potassium and calcium ions of isolated cerebral arteries. Amer. J. Physiol. 227: 1206-1211.

Towart R (1981) The selective inhibition of serotonin-induced contractions of rabbit cerebral vascular smooth muscle by calcium-antagonistic dihydropyridines. An investigation of the mechanism of action of nimodipine. Circ. Res. 48: 650-657.

Towart $R$ (1982) The pathophysiology of cerebral vasospasm, and pharmacological approaches to its management. Acta Neurochir. 63: 253-258.

Towart R, Kazda S (1979) The cellular mechanisms of action of nimodipine (BAY e 9736), a new calcium antagonist. Brit. J. Pharm. 67: 409-410.

Towart R, Perzborn E (1981) Nimodipine inhibits carbocyclic thromboxane-induced contractions of cerebral arteries. Eur. J. Pharm. 69: 213-215.

Towart R, Wehinger E, Meyer H, Kazda S (1982) The effects of nimodipine, its optical isomers and metabolites on isolated vascular smooth muscle. Arzneim. Forsch. 32: 338-346.

Van Breemen C, Siegel B, Kalinoski L, Zera P, Hwang O (1980) The $\mathrm{Ca}^{++}$cycle in arterial smooth muscle. In $\mathrm{RH}$ Wilkins (Ed.), Cerebral Arterial Spasm. Baltimore, Williams \& Wilkins, pp. 699.

Van Nueten JM, Vanhoutte PM (1981) Calcium entry blockers and vasospasm. In Vanhoutte PM, Leusen I (Eds.), Vasodilatation. New York, Raven Press, pp. 459-468.

Varsos VG, Liszczak TM, Han DH, Kistler JP, Vielma J, Black PM, Heros RC. Zervas NT (1983) Delayed cerebral vasospasm is not reversible by aminophylline, nifedipine, or papaverine in a "twohemorrhage" canine model. J. Neurosurg. 58: 1 [-17.

Weir BKA (1980) The effect of vasospasm on morbidity and mortality after subarachnoid hemorrhage from ruptured aneurysm. In RH Wilkins (Ed.), Cerebral Arterial Spasm. Baltimore, Williams \& Wilkins, pp. 699.

Weir B, Grace M, Hansen J, Rothberg C (1978) Time course of vasospasm in man. J. Neurosurg. 48: 173-178.

Weiss GB (1981) New Perspectives on Calcium Antagonists. American Physiological Society, Bethesda. Distributed by William and Wilkins Co., Baltimore, pp. 241.

White RP, Cunningham MP, Robertson JT (1982) Effect of the calcium nimodipine on contractile responses of isolated canine basilar arteries induced by serotonin, prostaglandin $F_{2^{a}}$, thrombin, and whole blood. Neurosurgery 10: 344-348. 